\title{
APLIKASI PINTAR BAHASA INGGRIS UNTUK SISWA SMP MUHAMMADIYAH SELATPANJANG BERBASIS ANDROID
}

\author{
Adhamdi Tria Putra Abza ${ }^{1)}$ \\ ${ }^{1}$ Manajemen Informatika, AMIK Selat Panjang, J1. Terpadu Dorak Selatpanjang \\ email: dham.abza@gmail.com
}

\begin{abstract}
Bahasa inggris sangat mendominasi aspek komunikasi antar bangsa di seluruh dunia karena telah diakui secara internasiona, oleh karena itu Bahasa Inggris menjadi mata pelajaran wajib di bidang pendidikan. Pada Sekolah Menengah Pertama (SMP) Muhammadiyah Selatpanjang juga menetapkan bahasa inggris sebagai salah satu bidang studi wajib diajarkan kepada muridnya. Oleh karena itu diperlukan suatu aplikasi yang merangkum materi pembelajaran bahasa inggris sebagai media pendukung pembelajaran. Aplikasi pintar bahasa inggris dibuat dengan menggunakan bahasa pemrograman android app invertor. Aplikasi pintar bahasa inggris ini merupakan program yang memudahkan para siswa dalam memahami materi bahasa inggris yang dapat dipelajari di rumah.
\end{abstract}

Keywords: Bahasa Inggris, App Invertor, Belajar

\section{PENDAHULUAN}

Pada Sekolah Menengah Pertama (SMP) Muhammadiyah Selatpanjang menetapkan bahasa inggris sebagai salah satu bidang studi wajib diajarkan kepada muridnya. Guru bidang studi yang mengajarkan Bahasa Inggris di SMP Muhammadiyah Selatpanjang menganggap telah menyampaikan pembelajarannya dengan baik akan tetapi para murid masih saja menganggap bahasa inggris pembelajaran sulit untuk dimengerti oleh murid. Hal ini dapat dilihat pada saat guru bidang studi bahasa inggris menerangkan pembelajaran kemudian mengadakan latihan soal dan ulangan ternyata masih banyak dari para murid yang mendapatkan nilai yang dibawah rata-rata.

Oleh karena itu, diperlukan suatu aplikasi yang merangkum materi pembelajaran bahasa inggris untuk memudahkan para siswa dalam memahami pembelajaran di rumah.

Berdasarkan hal tersebut, penulis mencoba mengembangkan aplikasi yang

dapat memberikan kemudahan dalam pembelajaran murid dan meningkatkan kualitas individual murid untuk membantu para murid dalam proses belajar bahasa inggris di rumah dengan menggunakan media smartphone dan sebagai pendamping pembelajaran yang dipelajari dari sekolah yang diajarkan oleh guru bidang studi.

\section{METODE PENELITIAN}

Dalam menyelesaikan penelitian ini, penulis mengumpulkan data-data dengan beberapa metode antara lain :

1. Wawancara

Melakukan percakapan secara langsung dengan narasumber yaitu guru bidang studi bahasa inggris.

2. Observasi

Pengamatan secara langsung di sekolah SMP Muhammadiyah Selatpanjang.

3. Dokumentasi

Mengumpulkan data-data dari buku bahasa inggris yang digunakan dalam proses mengajar.

4. Kajian Pustaka 
Meliput, mencari, membaca, dan menelaah laporan-laporan penelitian dan bahan pustaka yang membuat teori-teori yang relevan dengan penelitian yang akan dilakukan.

5. Kajian Internet

Pencarian data untuk melengkapi data penulisan yang dibutuhkan diambil dari sumber di internet.

\section{HASIL DAN PEMBAHASAN}

\section{A. Flowchart Aplikasi Pintar Bahasa Inggris}

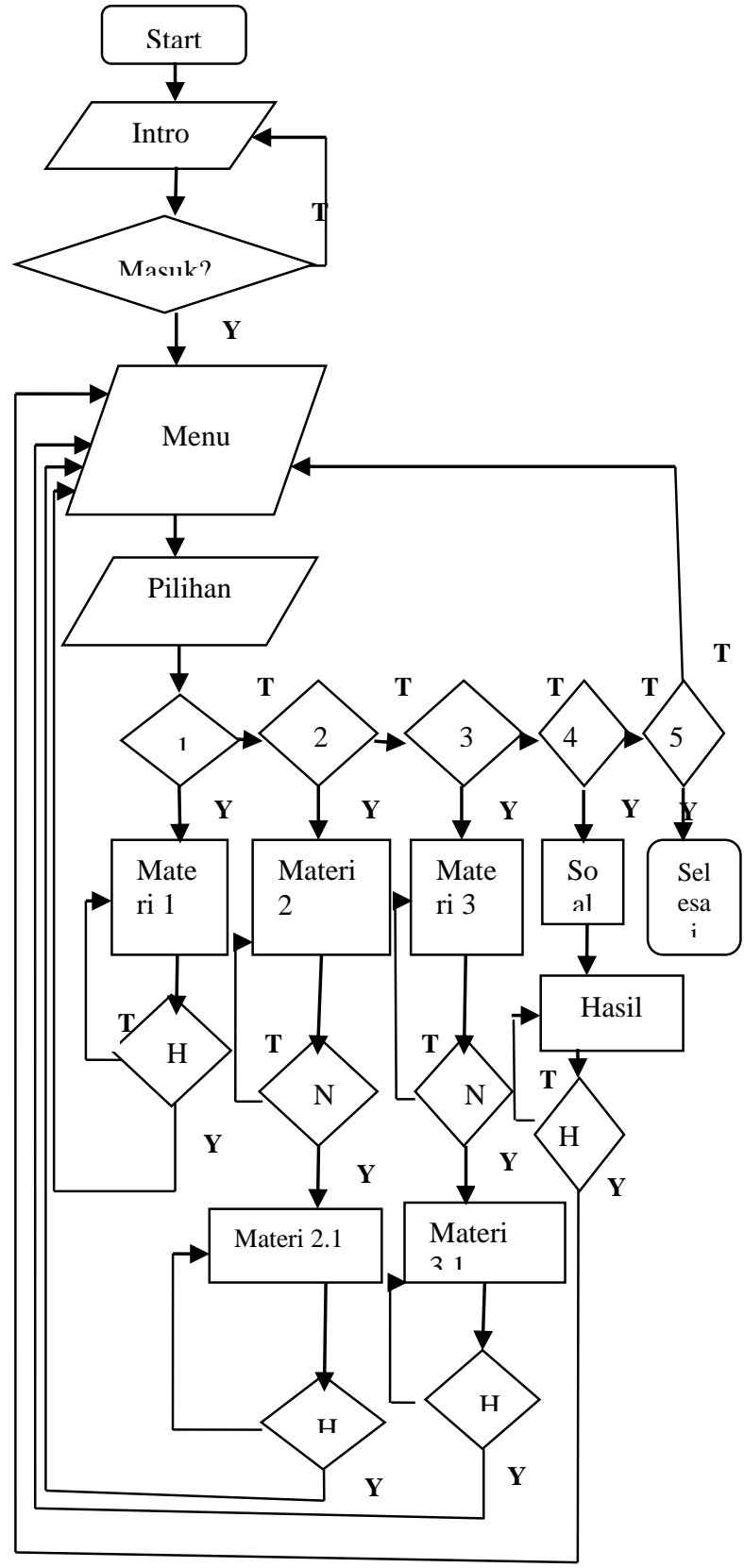

\section{Gambar 1. Flowchart Aplikasi Bahasa Inggris}

Flowchart pada Gambar 1 di mulai dari start dan berlanjut ke tampilan intro, kemudian jika button ayo belajar diklik maka akan muncul tampilan menu di mana terdapat pilihan yang dapat terbuka dengan mengklik pilihan tersebut, pilihan yang dapat dipilih yaitu seperti good morning, good morning and afternoon, good evening, dan profil. Ketika mengklik pilihan button good morning, maka akan keluar materi mengenai good morning dan jika mengklik button home maka akan kembali ke tampilan menu.

Di tampilan menu jika mengklik pilihan good morning and good afternoon maka akan keluar materi mengenai good morning and good afternoon dan ketika mengklik button next maka akan keluar materi kedua tentang good afternoon kemudian jika mengklik button home maka akan kembali ke tampilan menu.

Di tampilan menu jika mengklik pilihan good evening maka akan keluar materi mengenai good evening dan ketika mengklik button next maka akan keluar materi kedua tentang good evening kemudian jika mengklik button home maka akan kembali ke halaman utama. Di tampilan menu jika mengklik pilihan question maka akan keluar beberapa soal yang bisa dijawab dan dipilih jawaban yang dikira benar setelah menjawab kelima soal maka akan muncul skor yang diperoleh beserta kunci jawaban yang benar kemudian akan ada tombol home jika diklik akan kembali ke tampilan menu. Di tampilan menu jika mengklik pilihan profil maka akan keluar profil dari penulis atau yang membuat aplikasi dan jika mengklik button home maka akan kembali ke tampilan menu. Pada akhir flowchart ada button keluar jika memilih pilihan yes, $i$ do maka aplikasi akan keluar dan selesai. 


\section{B. Hasil Implementasi Sistem}

1. Tampilan Intro

Tampilan intro merupakan halaman awal yang muncul pada saat aplikasi dibuka yang bisa dilihat pada Gambar 2.

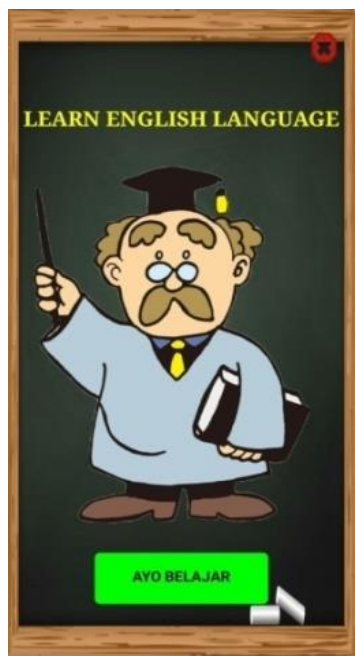

Gambar 2. Tampilan Intro

\section{Tampilan Menu Utama}

Tampilan menu utama merupakan pilihanpilihan menu pada aplikasi yang dapat dilihat pada Gambar 3.

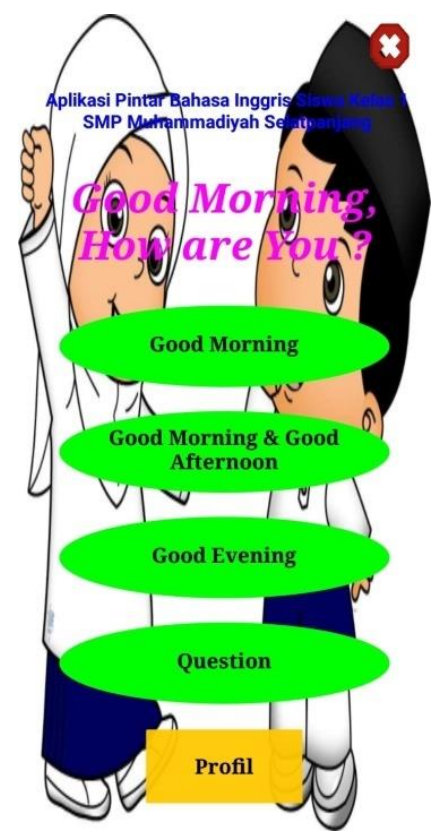

Gambar 3. Tampilan Menu Utama

\section{Tampilan Materi Good Morning}

Tampilan materi good morning merupakan tampilan materi pembelajaran yang membahas tentang bahasa inggris good morning yang dapat dilihat pada Gambar 4 dan Gambar 5.

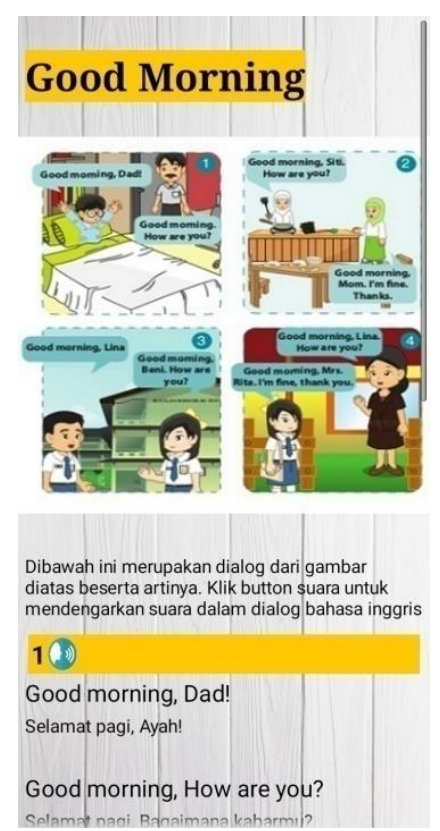

Gambar 4. Tampilan Pertama Good Morning 


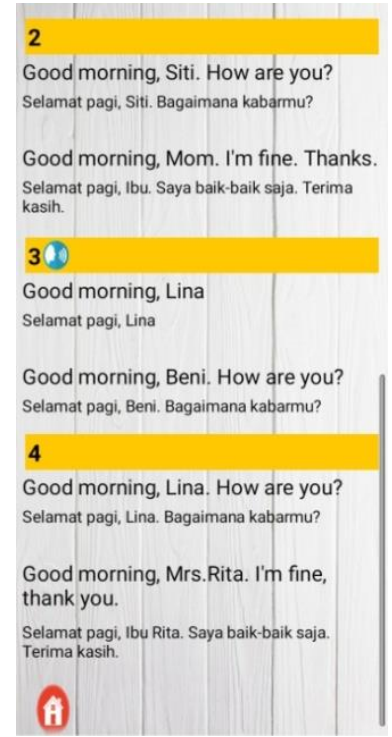

\section{Gambar 5. Tampilan Kedua Good Morning}

\section{Tampilan Materi Good Morning} dan Good Afternoon

Tampilan materi good morning dan good afternoon merupakan tampilan materi yang membahas pembelajaran kata-kata good morning dan good afternoon yang dapat dilihat pada Gambar 6, Gambar 7 dan Gambar 8.

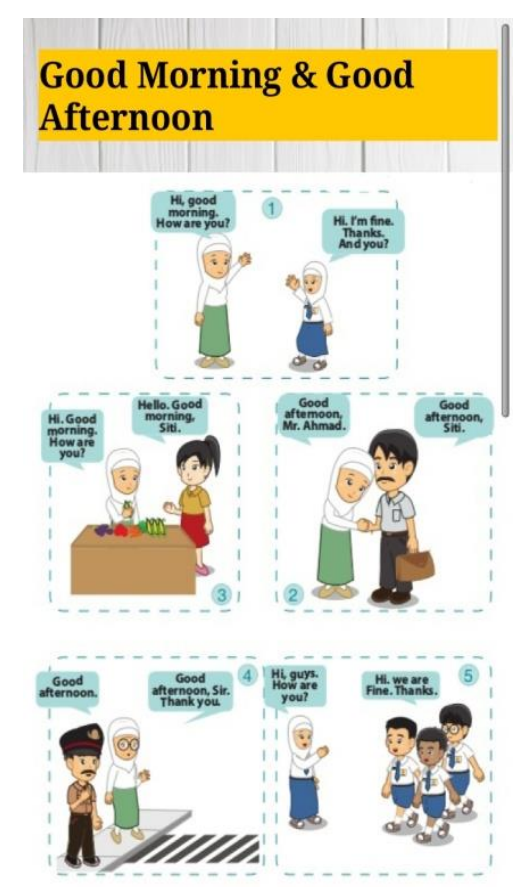

Dibawah ini merupakan dialog dari gambar diatas beserta artinya. Klik button suara untuk mendengarkan suara dalam dialog bahasa inggris

\section{Gambar 6. Tampilan Pertama Good Morning \& Good Afternoon}

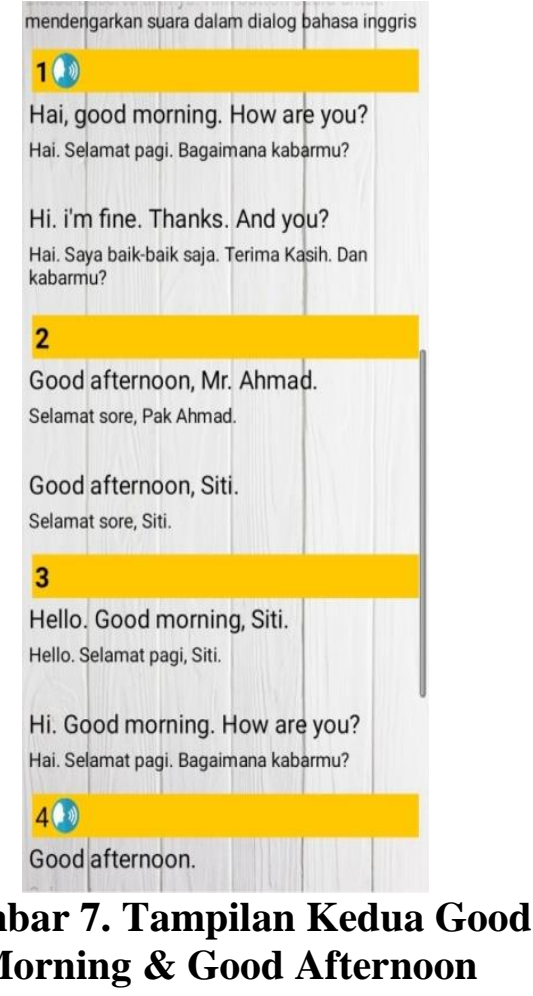




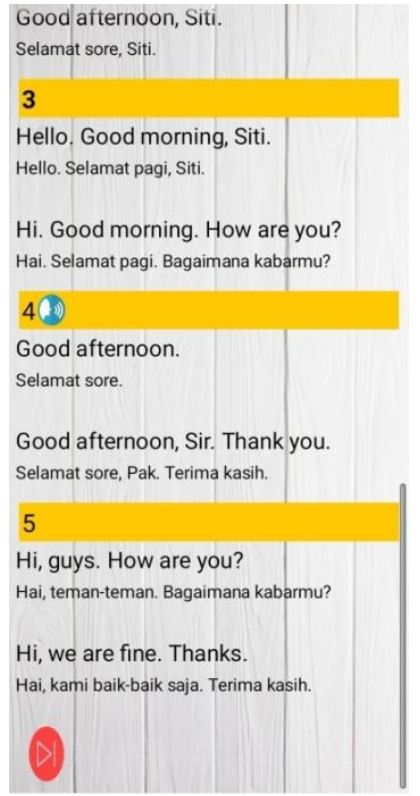

\section{Gambar 8. Tampilan Ketiga Good Morning \& Good Afternoon}

\section{Tampilan Materi Good Evening} Tampilan materi good evening adalah tampilan yang membahasa pembelajaran bahasa inggris tentang kosakata good evening yang dapat dilihat pada Gambar 9, Gambar 10 dan Gambar 11.

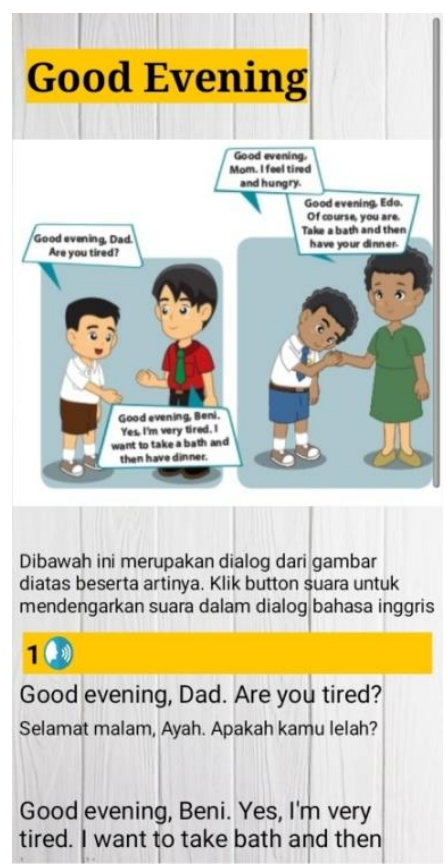
Gambar 9. Tampilan Pertama Good Evening
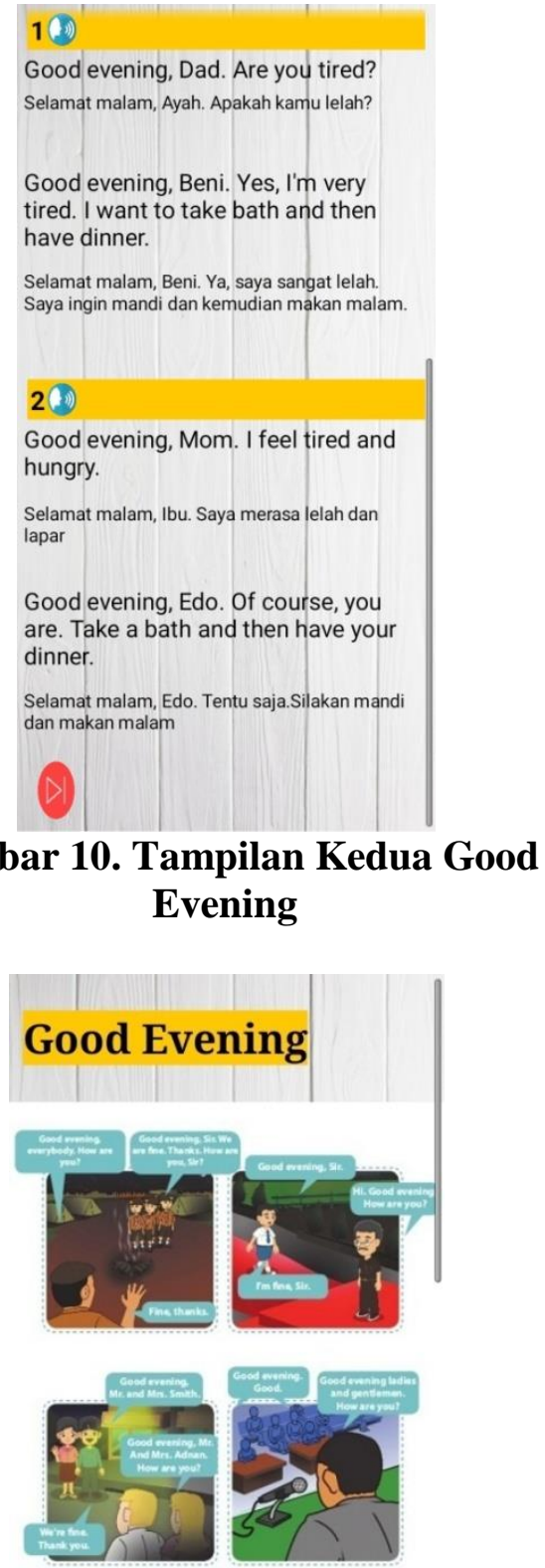

Dibawah ini merupakan dialog dari gambar diatas beserta artinya. Klik button suara untuk mendengarkan suara dalam dialog bahasa inggris

1 (1)

Good evening, everybody. How are you?

\section{Gambar 11. Tampilan Ketiga Good Evening}

\section{Tampilan Question}

Tampilan question merupakan tampilan yang berisi tentang pertanyaan-pertanyaan dari pembelajaran yang di bahas di menu materi yang dapat dilihat pada Gambar 12, Gambar 13 dan Gambar 14. 


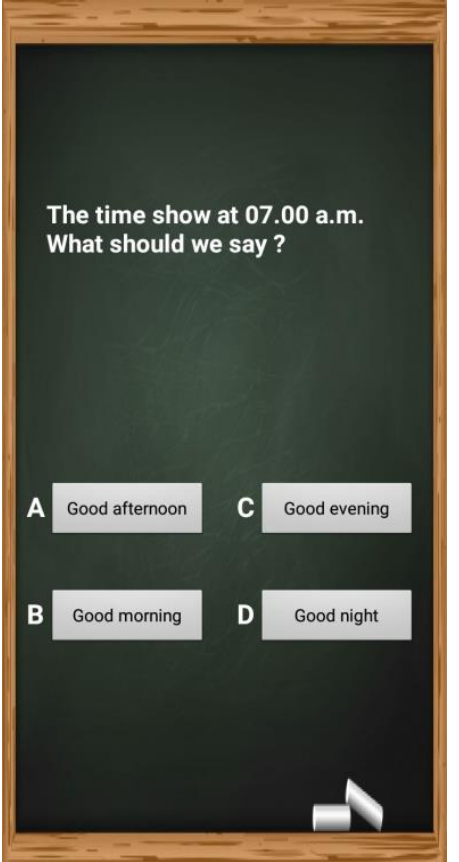

Gambar 12. Tampilan Pertama Question

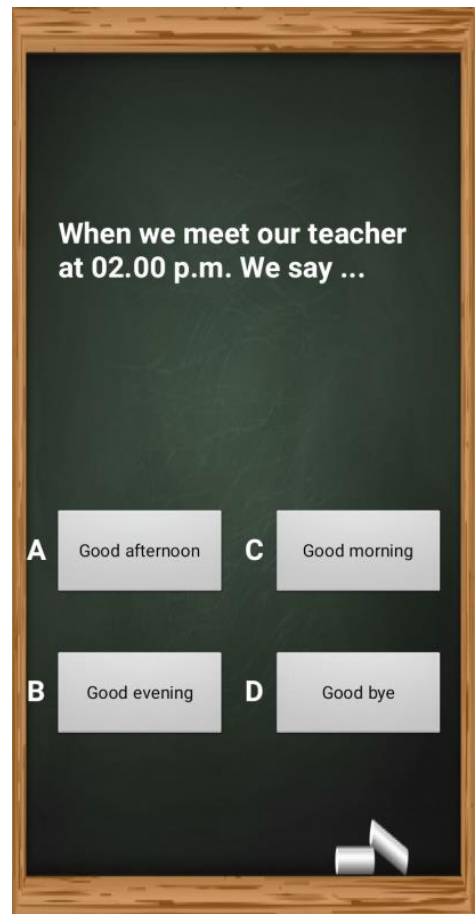

Gambar 13. Tampilan Kedua Question

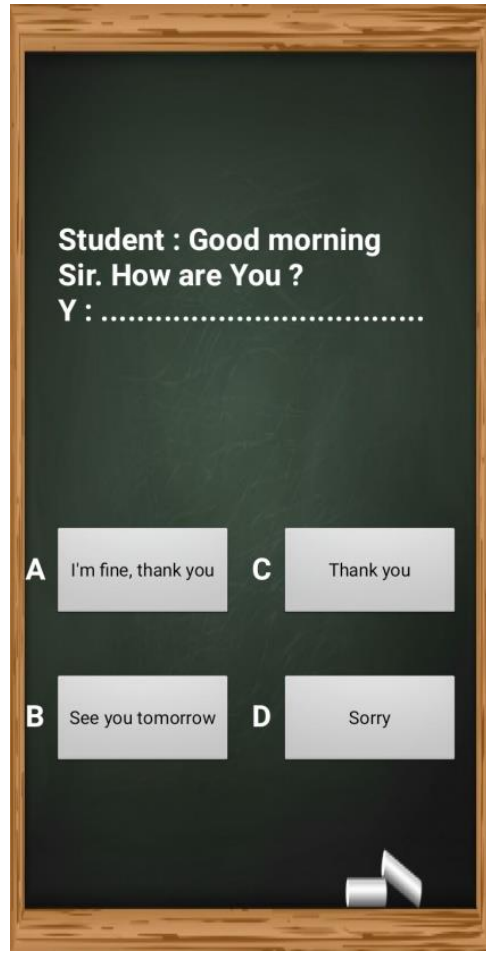

\section{Gambar 14. Tampilan Ketiga Question}

\section{Tampilan Skor}

Tampilan skor merupakan hasil nilai dari jawaban-jawaban dari pertanyaanpertanyaan yang telah dikerjakan yang dapat dilihat pada Gambar 15.

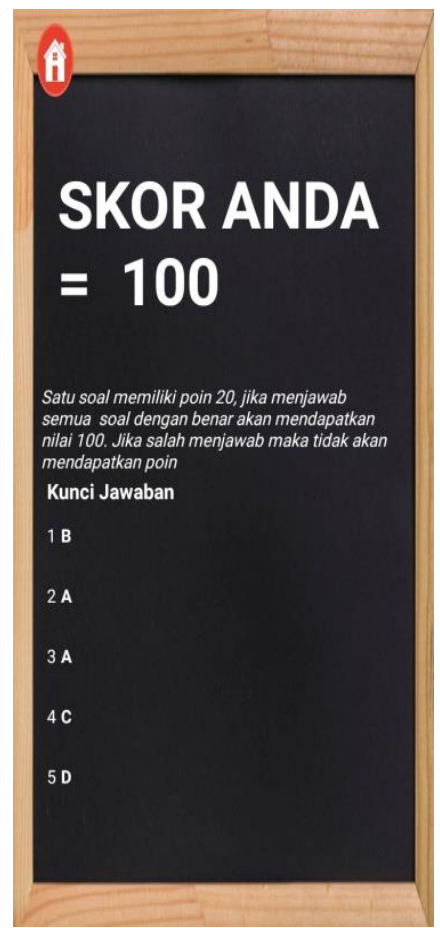

Gambar 15. Tampilan Skor 


\section{KESIMPULAN}

Berdasarkan pembahasan yang penulis uraikan tentang aplikasi pintar Bahasa Inggris murid SMP Muhammadiyah Selatpanjang, dengan menggunakan aplikasi pintar bahasa inggris, murid SMP Muhammadiyah Selatpanjang dapat dijadikan sebagai media pendukung untuk murid dalam belajar bahasa inggris dirumah yang berisi tentang materi pembelajaran berdasarkan buku pelajaran yang digunakan saat pembelajaran di kelas.

\section{DAFTAR PUSTAKA}

Wachidah, Siti, et all. (2017). Bahasa

Inggris When English Rings a

Bell. Jakarta: Penerbit Pusat

Kurikulum dan Perbukuan,

Balitbang, Kemendikbud.

Tim Smart Nusantara. (2017). Strategi

Kuasai Bahasa Inggris. Jakarta:

Penerbit Gramedia Widiasarana

Indonesia

Masitoh, Dewi. (2017). Step Up Kupas

Tuntas Pola Soal Bahasa Inggris

SMP/MTs Kelas VII, VIII dan

IX. Jakarta: Pustaka Widyatama

Ramadhani, Anis. (2013). Jurus Rahasia

Pintar Menguasai Android

Untuk Pemula. Jakarta: Kir

Direction

Azhari, Mukti Adi. (2017). Membuat

Game Edukasi dengan HTML5

dan Android Studio. Jakarta:

Lokomedia

Safaat H, Nazruddin. (2018). Android

Pemrograman Aplikasi Mobile

Berbasis Android Revisi Ketiga.

Bandung: Informatika 